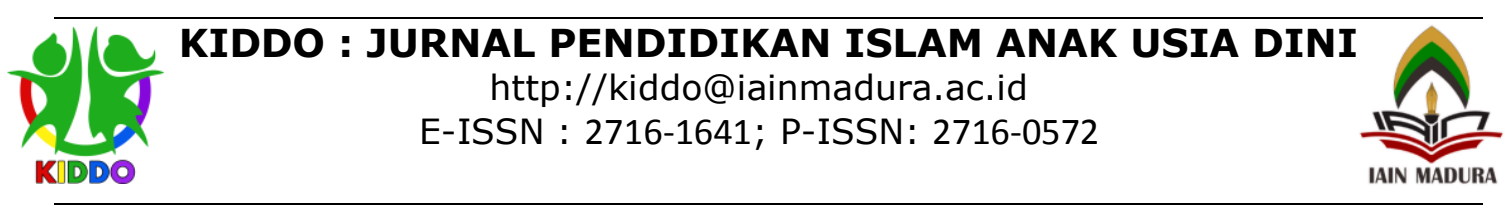

\title{
Penerapan Metode Tilawati dalam Pembelajaran Membaca Al-Qur'an pada Anak Usia Dini di RA Darul Ulum Mani'an Majungan Pademawu Pamekasan
}

\author{
Selfi Yatul Aini ${ }^{1}$, Rasidi ${ }^{2}$ \\ Institut Agama Islam Negeri Madura ${ }^{12}$, Indonesia \\ Selfiyatulaini@gmail.com
}

\begin{tabular}{l} 
Abstract \\
\hline This studyaims to determine the implementation of \\
the Tilawati Method in learning to read al-Qur'an \\
early childhood, the advantages and disadvantages of \\
inhibiting and supporting factors in the RA Darul \\
Reading the qur'an; \\
Early childhood. \\
research uses a descriptive qualitative approach in \\
the form of written words.Source of data used to \\
obtain data through observation, interview and \\
documentation. Interview is a question and answer \\
session with face to face about the problem under \\
study. Observation is a data collection technique \\
conducting careful research and systematic \\
recording. Documentation can be done by \\
researchcers to obtain supporting data about the \\
findings obtained in the field. Analysis of the data in \\
this study researchers through several stages, \\
namely data reduction, data presentation and \\
drawing conclusions. While checking the data is done \\
through an extension of participation, research \\
perseverance and triangulation. In this study, \\
researchers used source triangulation. The results of \\
this study indicate that:first,the application of the \\
Tilawati method in RA Darul Ulum went well major \\
barrier to the application of the Tilawati method. \\
Secondly, advantages the application of the tilawati \\
method, namely balancing the learning approach \\
classically and individually. The drawback is that for \\
those who do not pass smoothly it will also take a \\
long time because this method of passing is not
\end{tabular}


determined by the month or year. Third,(a) supporting factor, easy method so that it does not make the child depressed. (b) inhibiting factors, lack of facilities so that using only one approach.

\section{Abstrak}

Penelitian ini bertujuan untuk mengetahui penerapan metode tilawati dalam pembelajaran membaca alQur'an anak usia dini,kelebihan serta kekurangan, faktor penghambat dan pendukung di RA Darul Ulum Mani'an Majungan Pademawu Pamekasan. Penelitian ini menggunakan pendekatan kualitatif deskriptif berupa kata-kata tertulis. Sumber data yang digunakan untuk memperoleh data melalui observasi, wawancara dan dokumentasi. Wawancara adalah suatu kegiatan tanya jawab dengan tatap muka tentang masalah yang diteliti. Observasi adalah suatu teknik pengumpulan data yang dilakukan dengan cara mengadakan penelitian secara teliti, serta pencatatan secara sistematis.Dokumentasi dapat dilakukan oleh peneliti untuk memperoleh data-data pendukung tentang temuan-temuan yang diperoleh di lapangan.Analisis data dalam penelitian ini peneliti melalui beberapa tahap yaitu reduksi data, penyajian data dan penarikan kesimpulan. Sedangkan pengecekan data dilakukan melalui perpanjangan keikutsertaan, ketekunan peneliti dan triangulasi. Dalam penelitian ini peneliti menggunakan triangulasi sumber. Hasil penelitian ini menunjukkan bahwa: Pertama, penerapan metode tilawati di RA Darul Ulum berjalan dengan baik, walaupun masih terdapat faktor penghambat terhadap penerapan metode tilawati ini. Kedua, kelebihannya yaitu menyeimbangkan pendekatan pembelajaran secara klasikal dan individual.Adapun kekurangannya yaitu bagi yang tidak lancar lulusnya juga akan lama karena metode ini lulusnya tidak ditentukan oleh bulan/tahun.Ketiga, (a) faktor pendukung:metode yang mudah, sehingga tidak membuat anak tertekan (b) faktor penghambat:kurangnya sarana sehingga menggunakan satu pendekatan saja.

Diterima : 17 Oktober 2020; Direvisi: 5 Januari 2021; Diterbitkan: 25 Februari 2020 


\section{Pendahuluan}

Pendidikan merupakan aktivitas untuk mengembangkan seluruh potensi serta aspek kepribadian manusia yang berjalan seumur hidup sepanjang kehidupan manusia. Rupert C Lodge dalam Philosophy of Education yang dikutip oleh Jamaluddin menyatakan bahwa pendidikan itu menyangkut seluruh pengalaman (Jamaluddin Didin, 2010:35).Pembelajaran merupakan suatu proses perubahan, yaitu perubahan dalam perilaku sebagai hasil interaksi antara dirinya dengan lingkungannya dalam memenuhi hidupnya. Ketika pembelajaran dikaitkan dengan Al-Qur'an maka akan membentuk suatu pengertian pembelajaran Al-Qur'an dimana sumber pembelajaran berasal dari Al-Qur'an. Dalam mempelajari Al-Qur'an hal pertama yang perlu dilakukan untuk dapat lebih dalam mempelajarinya maka haruslah belajar tentang cara membacanya dahulu. Sebagaimana Allah SWT telah berfirman dalam Q.S Al-Alaq ayat $1-5$ :

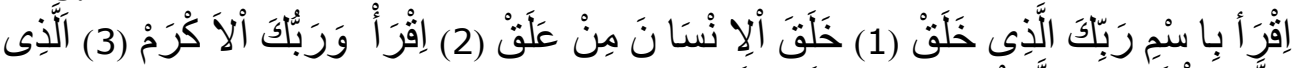

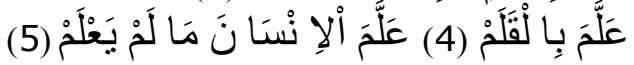

Artinya:"Bacalah dengan (menyebut) nama Tuhanmu yang menciptakan (1) Dia telah menciptakan manusia dari segumpal darah (2) Bacalah, dan Tuhanmulah Yang Maha Pemurah(3) Yang Mengajar (manusia) dengan pena (4) Dia mengajakan manusia apa yang tidak diketahuinya (5)."

Yang secara harfiah menurut Al-Maraghi dapat diartikan "Jadilah engkau seorang yang dapat membaca berkat kekuasaan dan kehendak Allah yang telah menciptakanmu walaupun engkau belum melakukannya"(Izzan Ahmad, 2012: 167). Allah yang telah menjadikan kemampuan untuk membaca dan memberikan ilmu yang tidak pernah mengetahui sesuatu apapun sebelumnya.Allah Maha Tahu untuk mewahyukan kepada manusia Al-Qur'an agar membacakannya kepada manusia lainnya.Allah berulangkali memerintahkan untuk membaca, karena memang manusia dapat membaca bila diperintah secara berulangkali.

Al-Qur'an adalah firman Allah yang telah diwahyukan kepada Rasulullah SAW melalui beberapa cara yang dikehendaki oleh Allah swt. Yang memuat hukum-hukum Islam dan berisi tuntunan-tuntunan bagi umat manusia untuk mencapai kehidupan yang bahagia di dunia dan di akhirat, lahir maupun batin.Ahmad Munir dan Sudarsono berpendapat bahwa apabila seseorang berkeinginan kuat untuk dapat membaca al-Qur'an dengan sebaik-baiknya, maka perlu penguasaan huruf, dan harakat(Srijatun, 2017: 26-27).

Dari penjelasan diatas dapat dipahami bahwa pembelajaran membaca Al-Qur'an sangat diperlukan dan dianjurkan pada diri umat muslim. Pembelajaran membaca Al-Qur'an yang dimulai pada usia dini dapat mempermudah pembentukan pondasi Qur'ani. Pada saat itu anak mudah menyerap informasi yang diberikan orang dewasa pada dirinya.Pola berfikir yang masih sederhana pada diri anak dan 
karakternya yang senang dengan keceriaan, membuat pendidik harus memutar otak untuk dapat membuat inovasi dalam pembelajaran agar tidak monoton dan membuat anak menjadi bosan.Begitu pun dalam pembelajaran membaca Al-Qur'an perlu adanya pembelajaran yang pas dan sesuai sehingga mampu memudahkan informasi yang diberikan diterima dengan baik dan sesuai harapan.

Dengan demikian dalam proses pelaksanaannya tentunya membutuhkan suatu metode yang dapat mempermudah tercapainya tujuan dari pendidikan tersebut. Metode mengajar dalam suatu pendidikan merupakan suatu kiat dalam pembelajaran, dengan kiat itu muatan-muatan pembelajaran kiranya menjadi hidangan lezat, dapat dinikmati dengan riang gembira oleh peserta didik, melalui interaksi edukatif tersebut.Dengan demikian perlu kiranya sebagai pendidik menciptakan inovasi baru atau mengembangkan inovasi dari suatu metode mengajar yang sudah ada atau belum ada.Dalam pelaksanaannya menciptakan ruang belajar yang tenang dan nyaman sangat penting demi mempermudah komunikasi antara pendidik dan peserta didik yang memungkinkan peserta didik lebih mudah dalam menyerap informasi ilmu yang disampaikan.

Metode adalah cara yang dalam fungsinya merupakan alat untuk mencapai tujuan(Zakiyah Darajat,et.al, cet.2: 91). Metode juga dapat diartikan sebagai tindakan-tindakan pendidik dalam lingkup peristiwa pendidikan untuk mempengaruhi siswa kearah pencapaian hasil belajar yang maksimal sebagaiman terangkum dalam tujuan pendidikan. Sedangkan metode pendidikan Qur'ani adalah suatu cara atau tindakan-tindakan dalam lingkup peristiwa pendidikan yang terkandung dalam Al-Qur'an. Metode tilawati merupakan metode belajar membaca Al-Qur'an dengan pendekatan yang seimbang antara "pembiasaan melalui klasikal" dan " kebenaran melalui individual" dengan teknik baca simak.

Sesuai hasil observasi awal, peneliti melakukan pengamatan dalam pembelajaran membaca Al-Qur'an di lembaga RA Darul Ulum, di sana sudah menerapkan metode Tilawati dalam pembelajaran membaca alQur'an.Lembaga RA Darul Ulum merupakan salah satu lembaga pendidikan yang ada di Dusun Mani'an Desa Majungan Pademawu Pamekasan. Lembaga tersebut berada di bawah naungan pondok pesantren Darul Ulum, yang mana dalam pembelajarannya tidak hanya terpaku dalam mengembangkan dan meningkatkan keenam aspek perkembangan pada anak usia dini, seperti aspek perkembangan sosial-emasional, agama dan moral, psikomorik, kognitif, seni,serta bahasa. Namun, di RA Darul Ulum juga terdapat pembelajaran membaca al-Qur'an.Dalam hal ini, metode yang digunakan dalam pembelajaran membaca al-Qur'an yang ada di lembaga RA Darul Ulum sangat berbeda dengan metode yang digunakan oleh lembaga-lembaga PAUD yang ada di Desa Majungan. Oleh karena itu, penulis tertarik untuk melakukan penelitian. Sehingga peneliti berinisiatif memberikan judul penelitian dengan judul Penerapan metode Tilawati dalam Pembelajaran Membaca al-Qur'an Anak Usia Dini di RA Darul Ulum Mani'an Majungan Pademawu Pamekasan. 
Berdasarkan uraian permasalahan pada konteks penelitian di atas, maka peneliti merumuskan masalah-masalah yang menjadi objek kajian pada penelitian ini agar terarah dan sesuai dengan apa yang telah direncanakan. Adapun fokus penelitian tersebut adalah:Pertama; 1. Bagaimana penerapan metode tilawati dalam pembelajaran membaca Al-Qur'an pada Anak Usia Dini di RA Darul Ulum Mani'an Majungan Pademawu Pamekasan; Kedua, 2. Apa saja kelebihan dan kekurangan pada penerapan metode tilawati dalam pembelajaran membaca Al-Qur'an pada Anak Usia Dini di RA Darul Ulum Mani'an Majungan Pademawu Pamekasan; Ketiga, 3. Apa faktor pendukung dan penghambat dalam penerapan metode tilawati dalam pembelajaran membaca Al-Qur'an pada Anak Usia Dini di RA Darul Ulum Mani'an Majungan Pademawu Pamekasan

Istilah pembelajaran berasal dari kata belajar, yaitu suatu aktivitas atau suatu proses untuk memperoleh pengetahuan, menungkatkan keterampilan, memperbaiki perilaku, sikap, dan mengukuhkan kepribadian. Pembelajaran adalah serangkaian kegiatan yang melibatkan informasi dan lingkungan yang disusun secara terencana untuk memudahkan siswa dalam belajar. Dalam UU SPN No. 20 tahun 2003 pembelajaran merupakan proses interaksi peserta didik dengan pendidik dan sumber belajar pada suatu lingkungan belajar (Majid, 2014: 4).

Penelitian ini penting dilakukan karena pembelajaran membaca AlQur'an sejak dini untuk mencetak generasi yang Qur'ani. Hal ini diperkuat oleh penelitian dari Nur Yasin yang berjudul Implementasi Metode Bil-Qolam Pembelajaran Membaca Al-Qur'an dalam Meningkatkan Kualitas Tajwid dan Pemahaman Mufradat di TPQ BilQolam Singosari Malang.

\section{Metode}

Penelitian ini menggunakan pendekatan kualitatif yang mana proses penelitian yang menghasilkan data deskriptif yang berupa kata-kata atau tulisan dari orang dan perilaku yang diamati (Moleong, 2011).Tujuan dari penelitian kualitatif adalah memahami realita empiris di balik fenomena yang ada secara mendalam, rinci, dan tuntas. Peneliti berusaha masuk ke dalam dunia konseptual subjek penelitian sehingga peneliti dapat mengerti apa dan bagaimana suatu pengertian yang dikembangkan oleh subjek di sekitar kehidupannya. Sedangkan jenis penelitian yang digunakan oleh peneliti adalah deskriptif, yaitu data yang dikumpulkan berupa kata-kata, gambar, dan bukan angka-angka. Selain itu, semua yang dikumpulkan akanmenjadi kunci terhadap apa yang diteliti oleh penelitisekaligus pengamat (Moleong, 2011: 11).

Sebagai pengamat, peneliti juga sebagai perencana, pelaksana pengumpulan data, dan menganalisis data serta juga melaporkan hasil penelitian. Sebagai instrument, peneliti merupakan alat yang melibatkan langsung dari keseluruhan proses penelitian, sehingga validitas dan keabsahan data lebih terjamin kebenarannya.Sedangkan instumen yang digunakan adalah berupa alat rekam yang dapat mempermudah peneliti melakukan pengumpulan data.Selain alat 
rekam, instrument yang digunakan peneliti adalah wawancara.Pengumpulan data yang digunakan dalam penelitian ini ada tiga yaitu: wawancara, observasi, dan dokumentasi.

\section{Hasil dan Pembahasan}

Berdasarkan hasil temuan yang peneliti temui dilapangan pada tanggal 16 maret 2020,mengenai pelaksanaan pembelajaran al-Qur'an dengan metode tilawati pada anak usia dini di RA Darul Ulum yaitu dimulai dari dasarnya dulu, yaitu dari jilid 1 sampai jilid seterusnya. Apabila siswa dan siswi sudah maksimal dalam membacaal-Qur'an metode tilawati baru dilanjut pada jilid selanjutnya.Dari hasil observasi yang sudah dilakukan oleh peneliti, peneliti menemukan beberapa temuan pada saat kegiatan belajar mengajar (KBM) berlangsung.

Terdapat penelitan yang berjudul "Penerapan Metode Tilawati dalam Pembelajaran Membaca al-Qur'an di TK 'Aisyiyah Bustanul Athfal VI Purwokerto" yang menjelaskan bahwa penerapan metode tilawati memerlukan langkah-langkah dalam menerapkannya (Eka Widyanti, 2015:4). Begitupun Pada pelaksanaan pembelajaran membaca alQur'an dengan metode tilawatipada anak usia dini di RA Darul Ulum terdapat beberapa langkah dalam pelaksanaannya. Guru mengucapkansalam terlebih dahulu sebagai pembuka dalam pembelajaran dan membaca doa bersama sebelum belajar sambil dipimpin oleh guru. Setelah itu, guru menanyakan kabar kepada siswa dan siswi dan guru mengkondisikan siswa dan siswi sebelum pembelajaran dimulai guru mengecek kehadiran siswa.Setelah selesai, siswa diarahkan untuk mengambil al-Qur'an metode tilawati didalam tasnya.

Pada kegiatan inti, guru mulai mengajarkan satu persatu siswa untuk membaca al-qur'an, kemudian apabila siswa lancar dan paham apa yang dibaca saat itu maka siswa dinaikkan kehalaman berikutnya, sedangkan apabila siswa belum lancar maka ditetapkan pada halaman tersebut dan diulangi pada keesokan harinya. Penilaian tersebut ditulis pada kartu prestasi siswa.Pada kegiatan selanjutnya yaitu pada kegiatan penutup,guru mengkondisikan siswa terlebih dahulu dan dilanjutkan dengan membaca doa sambil dipimpin oleh guru pembimbing. Setelah pembacaan doa sesudah belajar selesai, pembelajaran diakhiri dan dimulainya proses pembelajaran sesuai $\mathrm{RPPH}$ pada hari itu.

Menyangkut metode pembelajaran membaca al-Qur'an yang diterapkan di RA Darul Ulum yaitu metode Tilawati,terdapat sebuah penelitian yang berjudul Penerapan metode Tilawati dalam pembelajaran membaca al-Qur'an di MI Al-Falah Beran Ngawi(Siti Mutmainnah, $2011 ; 25)$. Yang mana penelitian tersebut menjelaskan bahwa dalam Penerapann metode Tilawati di MI Al-Falah Beran Ngawi, mempunyaiciri khas tersendiri yaitu dengan pendekatan Klasikal dan Individual.Pendekatan Klasikal dilaksanakan dengan 3 teknik yaitu:(a) Teknik 1(guru membaca siswa mendengarkan), (b)Teknik 2(guru membaca siswa menirukan), dan (c) Teknik 3 guru dan siswa samasama membaca. 
Pendekatan Individual dilaksanakan dengan teknik baca simak dengan sistem rolling, dengan harapan akhir siswa dapat membaca satuhalaman penuh secara keseluruhan.Sedangkan di RA Darul ulum hanya menggunakan satu pendekatan saja, yaitu: pendekatan individual dengan teknik baca simak.

Pada saat peneliti melakukan observasi di lembaga anak-anak merasa senang ketika belajar membaca menggunakan metode Tilawati, itu terlihat pada ekspresi anak yang enjoy serta tidak merasa tertekan karena memang metode ini mudah diterapkan serta menggunakan lagu dalam menerapkannya. Maka, dapat disimpulkan bahwa kelebihan dari metode tilawati adalah anak tidak bosan dalam belajar membaca al-Qur'an karena memang menggunakan lagu yaitu lagu yang digunakan dalam tilawah, kemudian metode tilawati ini juga menekankan pada pengetahuan peserta didik untuk dapat membaca secara tartil.

Metode Tilawati dalam pembelajaran membaca Al-Qur'an yaitu suatu metode atau cara belajar membaca Al-Qur'an dengan ciri khas menggunakan lagu Rast dan menggunakan pendekatan yang seimbang antara pembiasaan melalui klasikal dan kebenaran membaca melalui individual dengan tekhnik baca simak. Aplikasi pembelajaran pada metode ini menggunakan lagu Rast yaitu gerak ringan dan cepat(Siti Mutmainnah, 2011: 25). Metode Tilawati merupakan metode yang mudah untuk diterapkan karena memang dalam penerapannya menggunakan lagu yang tidak membuat anak menjadi bosan dalam belajar, akan tetapi terdapat kekurangan dalam menerapkan metode tilawati yaitu kenaikan jilid sesuai dengan kemampuan anak.Setiap anak memiliki kemampuan yang berbeda-beda.Hal itu terlihat pada tingkatan jilid yang diterapkan pada anak.Dalam satu kelas terdapat beberapa jilid, yakni jilid 1 sampai jilid 6 bahkan juga ada yang sudah menyelesaikan jilid sehingga lanjut ke al-qur'an 30 jus.

Dalam penerapan metode Tilawati dalam pembelajaran Al Qur'an di RA Darul Ulum terkadang menghadapi beberapa hambatan dan juga dukungan, faktor-faktor tersebut ada yang berasal dari lingkungan sekolah ataupun minat belajar siswa itu sendiri. Berikut ini beberapa faktor yang menjadi pendukung dan penghambat di RA Darul Ulum:

Faktor Pendukung yang pertama adalah Semangat guru dalam menerapkan metode tilawati. Guru sangatlah penting dalam proses pembelajaran, dan guru harus selalu semangat dalam menerapkannya. Pada penerapannya guru menggunakan pendekatan individual dan menggunakan lagu Rast.Pelaksanaan metode Tilawati ini dalam proses pembelajaran mempunyai 4 prinsip, yaitu:
a. Diajarkan secara praktis.
b. Menggunakan lagu Rast. 
c. Diajarkan secara klasikal menggunakan peraga.

d. Diajarkan secara individual dengan teknik baca simak menggunakan buku.

Faktor pendukung yang kedua, yaitu: Wali murid yang bisa diajak kerja sama dalam penerapan metode Tilawati. Banyaknya respon positif dari para wali siswa dan pihak lainnya terkait peningkatan kemampuan dalam hal membaca, menulis dan menghapal Al-Qur'an serta perkembangan wawasan terkait hukum bacaan Al-Qur'an pada diri anak mereka, semakin memacu semangat pihak sekolah, terutama para guru untuk semakin memperbaiki mutu pembelajaran Al-Qur'an dengan metode Tilawati ini.

Faktor selanjutnya adalah Metode Tilawati merupakan metode yang mudah, sehingga tidak membuat anak tertekan.Untuk mengajarkan buku tilawati penyusunan telah membuat pedoman pembelajarannya pada masing-masing jilid yang tertera pada halaman awal. Pedoman tersebut sebagai petunjuk pelaksaannya dari masing-masing jilid.

Selanjutnya adalah Faktor yang menghambat penerapan metode tilawati dalam pembelajaran membaca al-Qur'an yaitu. Pertama, Kurangnya sarana sehingga menggunakan satu pendekatan saja. Sarana merupakan salah satu faktor pendukung dalam proses pembelajaran seperti halnya alat peraga untuk menerapkan metode tilawati secara kalsikal, akan tetepi sarana tersebut tidak ada, sehingga menghambat pada pembelajaran membaca al-Qur'an menggunakan metode tilawati. Kedua, Sifat anak yang berebut, ingin lebih dulu mengaji padahal sudah ada giliran masing-masing. Hal ini akan terlihat seperti adanya pertikaian kecil antar anak. Pada proses pembelajaran metode Tilawati terdiri dari alokasi waktu, pendekatan pembelajaran, proses pembelajaran merupakan rangkaian kegiatan yang dilaksanakan oleh guru dan anak didik, dalam hal ini bisa peserta didik dan pendidik dalam kegiatan pengajaran dengan menggunakan sarana dan fasilitas pendidikan sehingga tercapai tujuan yang telah ditetapkan dalam kurikulum.

Hasil penelitian tentang penerapan metode Tilawati dalam pembelajaran membaca al-Qur'an pada anak usia dini di RA Darul Ulum Mani'an Majungan Pademawu Pamekasan adalah dilembaga tersebut menggunakan metode tilawati dalam belajar membaca alQur'an, sebelumnya meskipun masih terdapat kekurangan dan kelebihan, serta terdapat faktor pendukung dan penghambat dalam melaksanakannya. Akan tetapi tidak menjadi penghalang untuk membuat lembaga tersebut lebih maju. Sehingga dengan menerapkan metode tilawati di lembaga RA Darul Ulum dapat mencetak lulusan yang paham, lancar, serta fasih dalam membaca al-Qur'an khusunya menggunakan metode Tilawati. 


\section{Kesimpulan}

Berdasarkan hasil penelitian yang dilakukan, yaitu mengenai Penerapan metode tilawati dalam pembelajaran membaca Al-Qur'an pada Anak Usia Dini di RA Darul Ulum metode ini dilaksanakan setiap hari sebelum KBM dimulai yakni pada jam 07:00-08:00. Penerapan metode ini menggunakan pendekatan individual, serta mudah diterapkan karena dalam pembelajarannya menggunakan lagu yang tidak membuat anak bosan yaitu lagu Rast.Selanjutnya, terdapat beberapa kelebihan pada penerapan metode tilawati yaitu Menyeimbangkan pendekatan pembelajaran secara klasikal dan individual. Kedua,Disusun secara praktis sehingga mudah dipelajari. Ketiga, Menekankan pada kemampuan peserta didik untuk dapat membaca al-Qur'an secara tartil.Keempat, Menggunakan variasi lagulagu tilawah dalam membaca al-Qur'an sehingga tidak membosankan.Adapun kekurangan dari metode Tilawati yaitu bagi yang tidak lancar lulusnya juga akan lama karena metode ini lulusnya tidak ditentukan oleh bulan/tahun.

Kemudian, terdapat Faktor Pendukung dalam penerapan metode tilawati dalam pembelajaran membaca Al-Qur'an pada Anak Usia Dini di RA Darul Ulum antara lain: Semangat guru dalam menerapkan metode tilawati, Wali murid yang bisa diajak kerja sama dalam penerapan metode Tilawati, Metode yang mudah, sehingga tidak membuat anak tertekan. Sedangkan Faktor penghambatnya adalah Kurangnya sarana sehingga menggunakan satu pendekatan saja. Sifat anak yang berebut, ingin lebih dulu mengaji padahal sudah ada giliran masing-masing.

\section{Ucapan Terima kasih}

Penulis menyadari sepenuhnya bahwa proses penyusunan tugas akhir ini dapat selesai berkat bantuan dari berbagai pihak, bimbingan dan dorongan serta perhatiannya. Untuk itu penulis mengucapkan terimakasih yang sebesar-besarnya kepada kepala sekolah di RA Darul Ulum beserta seluruh guru RA Darul Ulum yang sudah membimbing dan memberikan izin kepada penulis untuk melakukan penelitian ini.

\section{Daftar Pustaka}

Ahmad, Izzan. (2012).Tafsir Pendidikan Studi Ayat-Ayat Berdimensi Pendidikan. Banten: Pustaka Aufa Media.

Darajat, Zakiyah,et.al. (2010). Metodik Khusus Pendidikan Agama Islam. Jakarta: Bumi Aksara.

Jamaluddin, Didin. (2010). Metode Pendidikan Anak. Bandung: Pustaka Al-Fikriis.

Juwariyah. (2010). Dasar-Dasar Pendidikan Anak dalam Al-Qur'an. Yogyakarta: Teras. 
Majid, Abdul. (2014). Strategi Pembelajaran. Bandung: PT Remaja Rosdakarya.

Moleong, Lexy J. (2011). Metodologi Penelitian Kualitatif. Bandung: PT. Remaja Rosdakarya.

Mulyono, Abdurrahman. (1999). Pendidikan Bagi Anak yang Berkesulitan Belajar. Jakarta: PT. Rineka Cipta.

Mutmainnah, Siti. (2011). Penerapan Metode Tilawati dalam Pembelajaran Membaca Al-Qur'an di MI al-Falah Beran Ngawi, Skripsi: IAIN Walisongo Semarang.

Potter, Bobbi De.dan Mike Hernarcki. (2009).Quantum Learning, Membiasakan Belajar Nyaman dan Menyenangkan, terj.Alwiyah Abdurrahman. Bandung: Kaifa.

Srijatun. (2017). Implementasi Pembelajaran Baca Tulis Al-Qur'an Dengan Metode Iqro' pada Anak Usia Dini di RA Perwanida Slawi Kabupaten Tegal, Jurnal pendidikan, UIN Walisongo Semarang.

Widyanti, Eka. (2015). Penerapan metode Tilawati dalam Pembelajaran Membaca Al-Qur'an di TK 'Aisyiyah Bustanul Athfal VI Purwokerto, Skripsi : IAIN Purwokerto. 